\title{
Regioselective Direct C-H Alkylation of NH Indoles and Pyrroles by a Palladium/Norbornene-Cocatalyzed Process
}

\author{
Lei Jiao, Thorsten Bach*
}

Lehrstuhl für Organische Chemie I and Catalysis Research Center (CRC), Technische Universität München, Lichtenbergstr. 4, 85747 Garching, Germany

Fax+49(89)28913315; E-mail: thorsten.bach@ch.tum.de

Received: 29.07.2013; Accepted: 03.08.2013

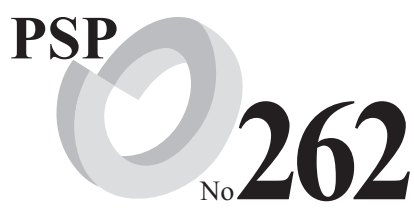

\begin{abstract}
Nitrogen-containing heterocycles, including $1 H$-indoles and electron-deficient $1 H$-pyrroles, undergo a palladium/norbornenecocatalyzed regioselective alkylation at the $\mathrm{C}-\mathrm{H}$ bond adjacent to the $\mathrm{NH}$ group. A primary alkyl halide is used as the electrophile and the reaction proceeds smoothly under mild conditions to give 2-alkyl-1H-indoles and 2-substituted or 2,3-disubstituted 5-alkyl-1 $H$-pyrroles in good yields.
\end{abstract}

Key words: catalysis, alkylations, regioselectivity, heterocycles, palladium, indoles, pyrroles

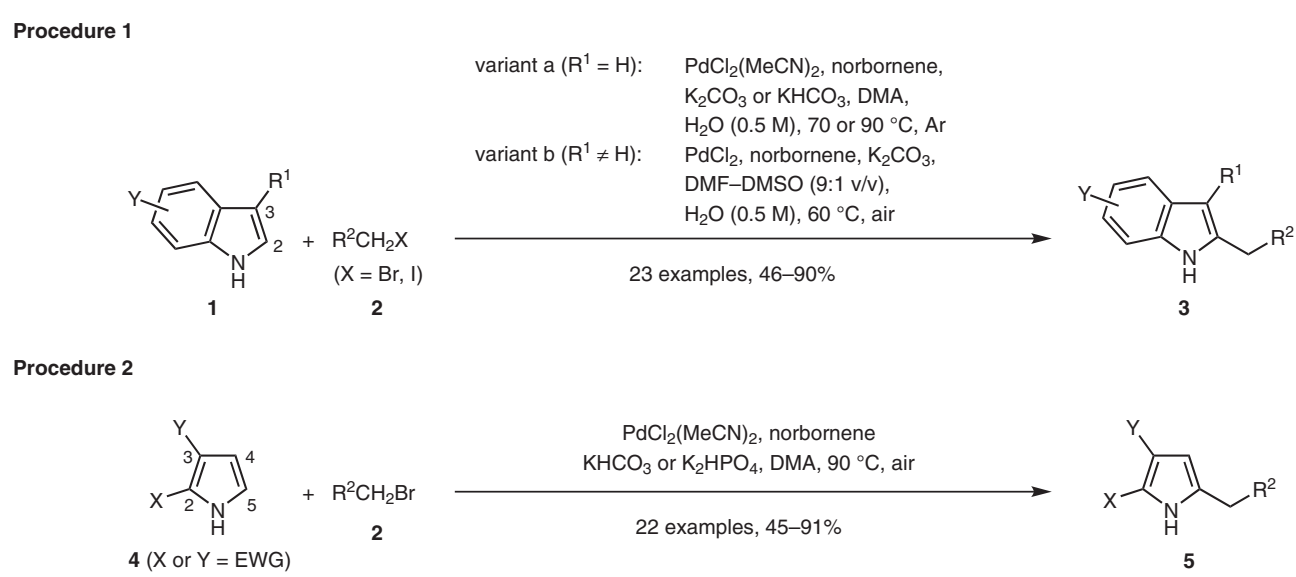

Scheme 1

\section{$1 \quad$ Introduction}

Indoles and pyrroles are two important classes of N-heterocycles that occur widely in natural products, drugs, and biologically active molecules. ${ }^{1}$ Alkyl-substituted indoles and pyrroles are of particular interest, because they form key structural elements of many structurally unique and biologically active natural products (Figure 1). ${ }^{2}$ However, few methods are available for constructing such structures by direct $\mathrm{C}-\mathrm{H}$ substitution. Although considerable advances have been made in the direct $\mathrm{C}-\mathrm{H}$ functionalization of indoles and pyrroles, ${ }^{3}$ the regioselective installation of an alkyl group onto these heterocyclic nuclei remains a challenge. Indoles undergo Friedel-Crafts alkylation selectively at the more electron-rich $\mathrm{C} 3$ position, ${ }^{4}$ but it is difficult to achieve direct $\mathrm{C} 2$ alkylation. ${ }^{5,6}$ In the case of pyrroles, Friedel-Crafts-type direct alkyla-

SYNTHESIS 2014, 46, 0035-0041

Advanced online publication: 17.09.2013

DOI: 10.1055/s-0033-1338523; Art ID: SS-2013-Z0526-PSP

(c) Georg Thieme Verlag Stuttgart · New York tion with alkyl electrophiles usually results in a mixture of regioisomers; ${ }^{7}$ other methods for regioselective alkylation of pyrroles are either circuitous or limited in substrate scope. ${ }^{8}$ Therefore, there remains a considerable need for efficient and regioselective methods for alkylation of indoles and pyrroles.

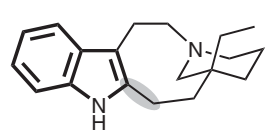

quebrachamine

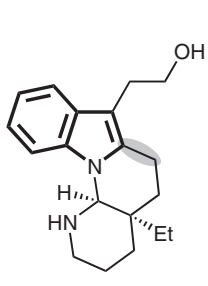

goniomitine

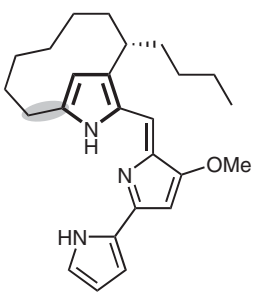

streptorubin B
Figure 1 Natural products containing an alkylindole or alkylpyrrole structure

Inspired by the Catellani reaction, ${ }^{9}$ we developed a palladium(II)/norbornene-cocatalyzed process that provides straightforward access to $\alpha$-alkyl-substituted indole and 
pyrrole derivatives from $\mathrm{NH}$ indoles ${ }^{10}$ and pyrroles $^{11}$ (Scheme 1). In this reaction, the N-heterocycle interacts with palladium(II) and norbornene to give intermediate $\mathbf{A}$, which then undergoes an intramolecular ortho-palladation to give palladaheterocycle $\mathbf{B}$ in the presence of a base (Scheme 2)..$^{10 b, 11}$ Subsequently, intermediate $\mathbf{B}$ reacts with the alkyl halide by oxidative addition, reductive elimination, norbornene expulsion, and protodepalladation to give the alkyl-substituted heterocycle. The role of norbornene in this process is to act as a transpositional cocatalyst that assists palladium in activating the $\alpha-\mathrm{C}-\mathrm{H}$ bond of $\mathrm{NH}$ indoles and pyrroles, providing excellent regioselectivities for the alkylation reactions (C2-alkylation on indole and C5-alkylation on 2-substituted and 2,3-disubstituted pyrroles). This reaction adds to the toolbox of synthetic methods for direct $\mathrm{C}-\mathrm{H}$ functionalization of $\mathrm{N}$ heterocycles.

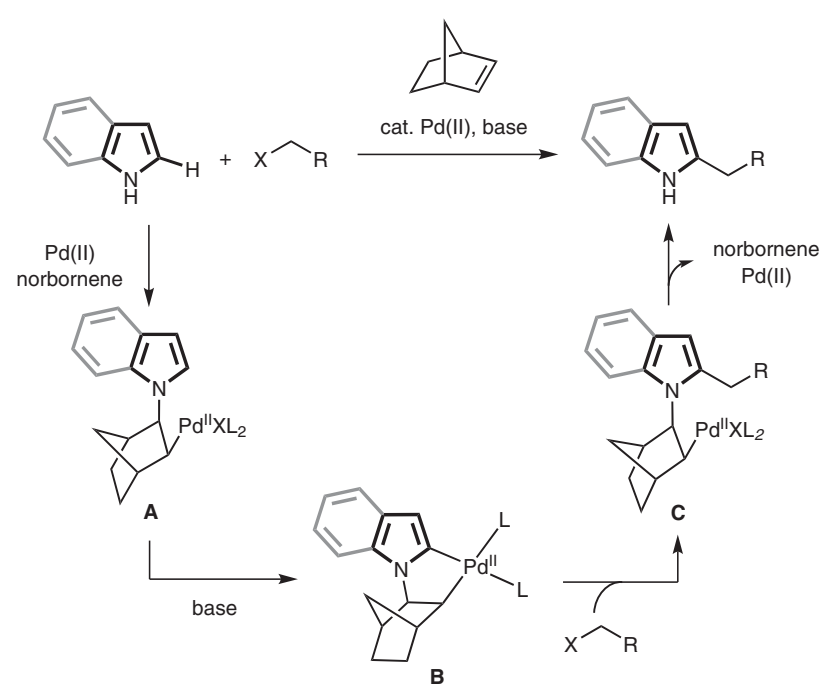

Scheme 2 The mechanism of the newly developed catalytic alkylation procedure

\section{Scope and Limitations}

The alkylation of $1 H$-indole (1a) with alkyl bromides $\mathbf{2 a -}$ j proceeded smoothly with the palladium(II)/norbornene cocatalytic system to give 2-alkyl- $1 H$-indoles regioselectively (Procedure 1, variant a). ${ }^{10}$ As shown in Table 1, a broad range of functionalized primary alkyl bromides are suitable as reaction partners. The reactions were conducted with bis(acetonitrile)dichloropalladium(II) as catalyst, norbornene as cocatalyst, and potassium carbonate as base in $N, N$-dimethylacetamide as solvent containing $0.5 \mathrm{M}$ water as an additive. In general, the 2-alkylation products were obtained in moderate to good yields and, in certain cases, minor amounts of the 2,3-dialkyl- $1 \mathrm{H}$-indole (4$19 \%$ ) were obtained as overalkylation byproducts. The steric effect of the alkyl bromide plays an important role in the alkylation reaction; primary alkyl bromides bearing a tertiary carbon center in the $\beta$-position reacted slowly (entries 2 and 6), whereas a secondary alkyl halide (2-io-
Table 1 Regioselective Direct Alkylation of $1 H$-Indole (1a) with Primary Alkyl Bromides 2a-j (Scheme 1, Procedure 1a)

\begin{tabular}{|c|c|c|c|c|}
\hline Entry $^{\mathrm{a}}$ & $\begin{array}{l}\text { Temp } \\
\left({ }^{\circ} \mathrm{C}\right)\end{array}$ & $\begin{array}{l}\text { Time } \\
\text { (h) }\end{array}$ & Product & $\begin{array}{l}\text { Yield }^{\mathrm{b}} \\
(\%)\end{array}$ \\
\hline 1 & 70 & 14 & $3 \mathbf{a a}$ & $67^{\mathrm{c}}$ \\
\hline 2 & 90 & 61 & $3 a b$ & $59^{\mathrm{c}}$ \\
\hline 3 & 70 & 14 & $3 a c$ & $58^{\mathrm{c}}$ \\
\hline 4 & 70 & 14 & $3 \mathrm{ad}$ & 82 \\
\hline 5 & 70 & 14 & $3 a e$ & 73 \\
\hline 6 & 90 & 20 & $3 \mathrm{af}$ & 65 \\
\hline 7 & 70 & 14 & 3ag & 72 \\
\hline 8 & 70 & 14 & 3ah & $56^{\mathrm{c}}$ \\
\hline 9 & 70 & 19.5 & 3ai & 65 \\
\hline 10 & 70 & 14 & 3aj & $66^{\mathrm{c}}$ \\
\hline
\end{tabular}

${ }^{a}$ Reaction conditions: indole $\mathbf{1}(1 \mathrm{mmol})$, primary alkyl bromide $\mathbf{2}$ (2 $\mathrm{mmol}), \mathrm{PdCl}_{2}(\mathrm{MeCN})_{2}(0.1 \mathrm{mmol})$, norbornene $(2 \mathrm{mmol}), \mathrm{K}_{2} \mathrm{CO}_{3}(2$ mmol), DMA + 0.5 $\mathrm{M} \mathrm{H}_{2} \mathrm{O}(5 \mathrm{~mL})$, under argon.

${ }^{\mathrm{b}}$ Yield of isolated product.

${ }^{c}$ A minor amount of the 2,3-dialkyl- $1 H$-indole was isolated as a byproduct.

dopropane) failed to react. The reaction of $1 H$-indole with ethyl 3-bromopropanoate failed to give the desired alkylation product as a result of elimination of hydrobromic acid under basic conditions to form ethyl acrylate. The use of an alkyl iodide instead of the corresponding alkyl bromide accelerated the reaction, but resulted in a considerable amount of the 2,3-dialkylation byproduct. Alkyl tosylates failed to react. Therefore, both reactivity and stability should be taken into account when choosing the alkyl coupling partners in this reaction.

$1 H$-Indoles bearing electron-donating or electron-withdrawing substituents were superior substrates in this 2-alkylation reaction (Procedure 1, variant a). ${ }^{10 a}$ Table 2 lists 
some results obtained with 5-, 6-, and 7-substituted $1 H$-indoles $\mathbf{1 b}-\mathbf{k}$ and various primary alkyl bromides. Interestingly, electron-deficient $1 H$-indoles usually afforded better yields of the 2-alkylindole products than did electron-rich $1 H$-indoles (compare entries $1-4$ with entries 511), but a weaker base, such as potassium bicarbonate or dipotassium hydrogen phosphate had to be used to prevent generation of undesired $N$-alkylindole byproducts. Halogen-substituted $1 H$-indoles were suitable substrates and successfully gave the corresponding halogen-substituted 2-alkyl-1H-indoles (for example, entries 4-8), allowing access to more-complex heterocyclic compounds through cross-coupling reactions.

The same procedure also permits the 2-alkylation of 3 substituted $1 H$-indole derivatives (Scheme 3$){ }^{10 \mathrm{~b}}$ The alkylation of 3-methyl-1 $\mathrm{H}$-indole (1 m) with butyl bromide proceeded more slowly than the alkylation of $1 H$-indole and gave a moderate yield of the 2,3-dialkylated indole 3mk. Therefore, an optimization study was conducted to improve this type of reaction, especially for more complex substrates. A modified procedure (Procedure 1, variant b) using alkyl iodide $\mathbf{2 n}$ as the electrophile, palladium(II) chloride as the catalyst, and $N, N$-dimethylformamide-dimethyl sulfoxide as a solvent mixture in an atmosphere of air resulted in good conversion and a high yield in the 2-alkylation of tryptophol derivative 1n (Scheme 3).
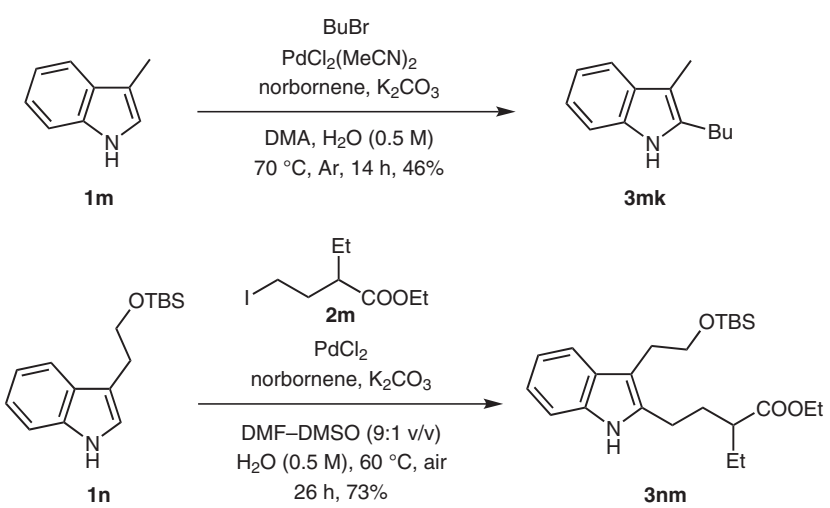

Scheme 3 Regioselective direct alkylation of 3-substituted $1 \mathrm{H}$-indoles (Scheme 1, Procedure 1b)

Because of the structural similarity between indole and pyrrole, our palladium(II)/norbornene-cocatalyzed alkylation process can also be applied to pyrrole derivatives. ${ }^{11}$ Interestingly, we found that the reaction worked properly only with electron-deficient pyrrole derivatives, and that it failed in the case of $1 \mathrm{H}$-pyrrole itself and other electronrich pyrroles. Given that the pyrrole nucleus is more electron rich and less acidic $\left(\mathrm{p} K_{\mathrm{a}}=23\right)$ than indole $\left(\mathrm{p} K_{\mathrm{a}}=20.95\right),{ }^{12}$ it is possible that electron-deficient pyrroles meet the electronic requirement of this reaction more closely. Alkyl 1H-pyrrole-2-carboxylates were found to be ideal substrates, and they underwent smooth 5-alkylation reactions with various primary alkyl bromides. In a slight departure from Procedure 1, these reactions were
Table 2 Regioselective Direct Alkylation of Substituted $1 H$-Indoles 1b-k with Primary Alkyl Bromides 2 (Scheme 1, Procedure 1a)

\begin{tabular}{lll}
\hline Entry $^{\mathrm{a}} \begin{array}{l}\text { Base } \\
\text { (equiv) }\end{array}$ & $\begin{array}{l}\text { Time Product } \\
\text { (h) }\end{array}$ & $\begin{array}{l}\text { Yield }^{\mathrm{b}} \\
(\%)\end{array}$
\end{tabular}

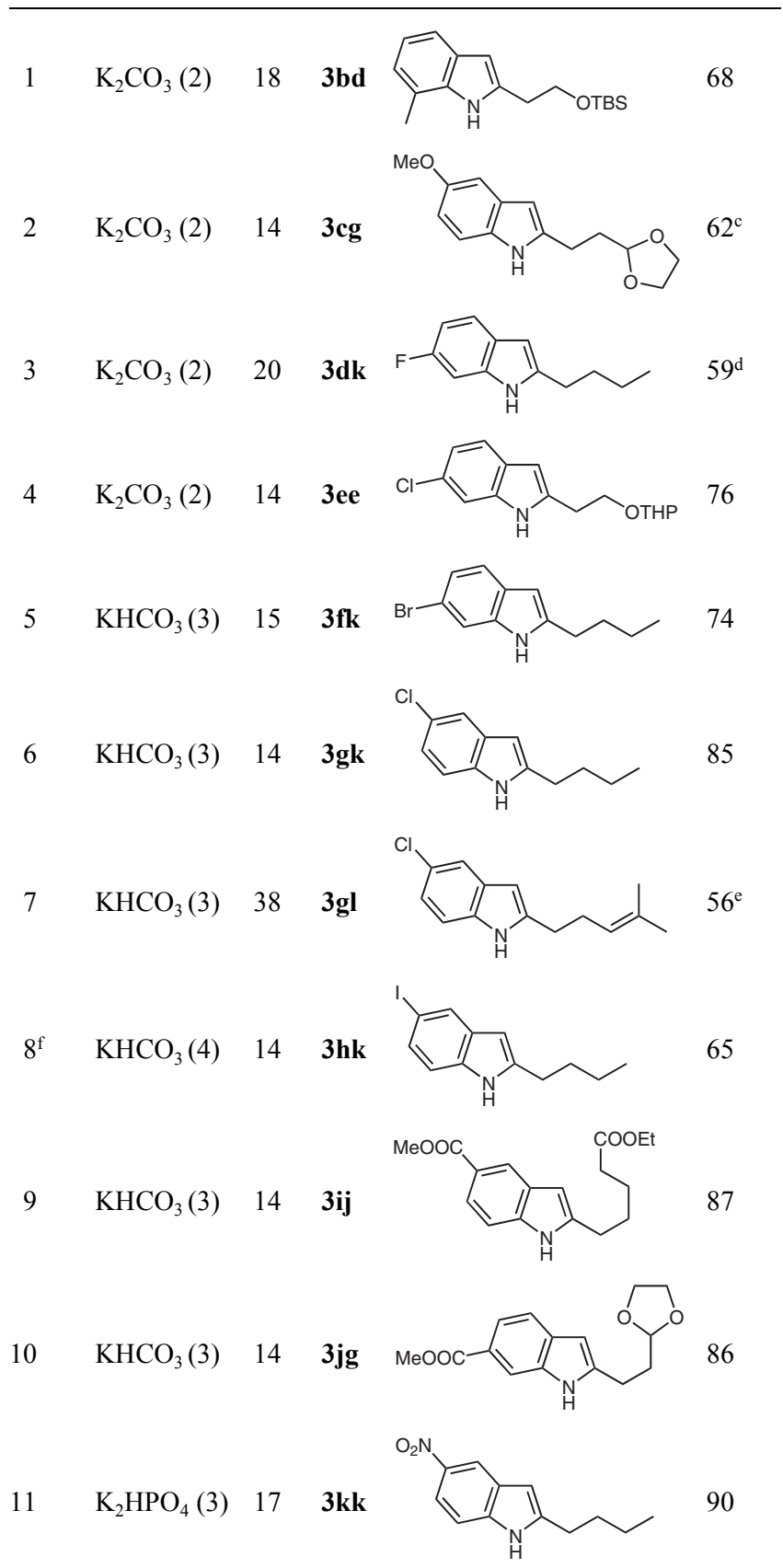

${ }^{a}$ Reaction conditions: indole $\mathbf{1}(1 \mathrm{mmol})$, primary alkyl bromide $\mathbf{2}$ (2 $\mathrm{mmol}), \mathrm{PdCl}_{2}(\mathrm{MeCN})_{2}(0.1 \mathrm{mmol})$, norbornene ( $\left.2 \mathrm{mmol}\right)$, base, DMA $+0.5 \mathrm{M} \mathrm{H}_{2} \mathrm{O}(5 \mathrm{~mL}), 70^{\circ} \mathrm{C}$, under argon.

${ }^{\mathrm{b}}$ Yield of isolated product.

c $23 \%$ of the indole substrate was recovered.

${ }^{\mathrm{d}} \mathrm{A}$ minor amount of 2,3-dialkyl- $1 H$-indole was isolated as a byproduct.

e $24 \%$ of the indole substrate was recovered.

$\mathrm{f} 4$ equiv of $\mathrm{BuBr}$ were used.

conducted by using potassium bicarbonate as a mild base in dry $N, N$-dimethylacetamide at $90{ }^{\circ} \mathrm{C}$ under air (Procedure 2). Table 3 shows some typical examples of 5-alkyl- 
ation reactions of pyrrole-2-carboxylates $\mathbf{4 a - c}$. The yields were generally good to excellent, and in all cases a single regioisomer was obtained. Although higher temperatures and longer reaction times were required for satisfactory conversion, this reaction, like the indole alkylation reaction, showed good tolerance to a range of functional groups. A limitation of this reaction is that is appears to be restricted to $1 H$-pyrrole-2-carboxylates as substrates; 2cyano-, 2-(dimethylaminocarbonyl)-, 2-formyl-, and 2acetyl-substituted $1 H$-pyrroles failed to give the desired products. Methyl $1 H$-pyrrole-3-carboxylate gave a mixture of 5-alkylation and 2,5-dialkylation products in low yield. Therefore, this procedure is best suited for the alkylation of alkyl $1 H$-pyrrole-2-carboxylates.

Procedure 2 can also be applied to a series of 2,3-disubstituted electron-deficient $1 H$-pyrroles $4 \mathbf{d}-\mathbf{i}$ (Table 4$).{ }^{11}$ These substrates gave 5-alkylation products regioselectively, albeit in lower yields than pyrrole-2-carboxylates. Both alkoxycarbonyl and acyl groups can be used as electron-withdrawing substituents on either the C2- or the C3position of pyrrole, although pyrrole carboxylates were found to be superior. A chlorinated pyrrole substrate $\mathbf{4 i}$ underwent smooth alkylation to give the chloro-substituted alkylpyrrole 5iq in high yield (entry 9). Because many methods have been reported for synthesizing 2,3-disubstituted electron-deficient pyrroles, ${ }^{13}$ a combination of these methods and the present 5-alkylation procedure provides regioselective access to a range of advanced functionalized pyrrole derivatives.

The utility of the alkylation method for constructing $\alpha$-alkylated N-heterocycles was showcased by its successful application in total syntheses of the Aspidosperma alkaloids aspidospermidine (6) and goniomitine (7) ${ }^{10 \mathrm{~b}}$ and the lipophilic pyrrole natural product mycalazal $14(8) .{ }^{11}$ In the syntheses of aspidospermidine and goniomitine, the indole alkylation protocol permitted an unprecedented synthetic strategy in which the creation of the indole C2alkyl bonds served as key steps in building the core structures of the two natural products. The syntheses were completed via the key intermediates 3ai and 3nm, respectively. In the synthesis of mycalazal 14, reduction of the pyrrole 5-tetradecylation product 5aa was carried out to afford the target molecule (Scheme 4).

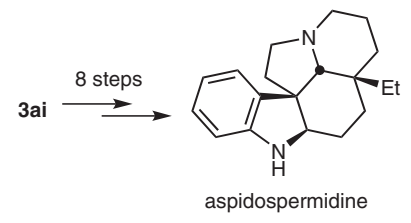

(6)

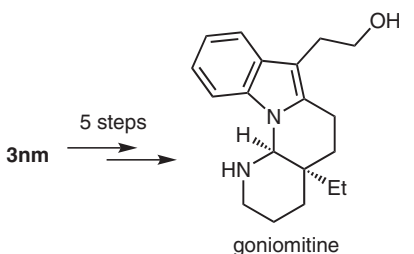

(7)

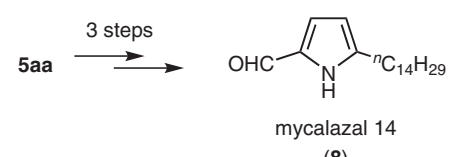

(8)
Scheme 4 Natural products aspidospermidine (6), goniomitine (7), and mycalazal 14 (8) synthesized through regioselective direct $\alpha$-alkylation of $\mathrm{N}$-heterocycles

Table 3 Regioselective Direct Alkylation of Electron-Deficient $1 H$ Pyrroles 4a-c with Primary Alkyl Bromides 2 (Scheme 1, Procedure 2)

\section{Entry $^{\mathrm{a}}$ Time Product}

(h)

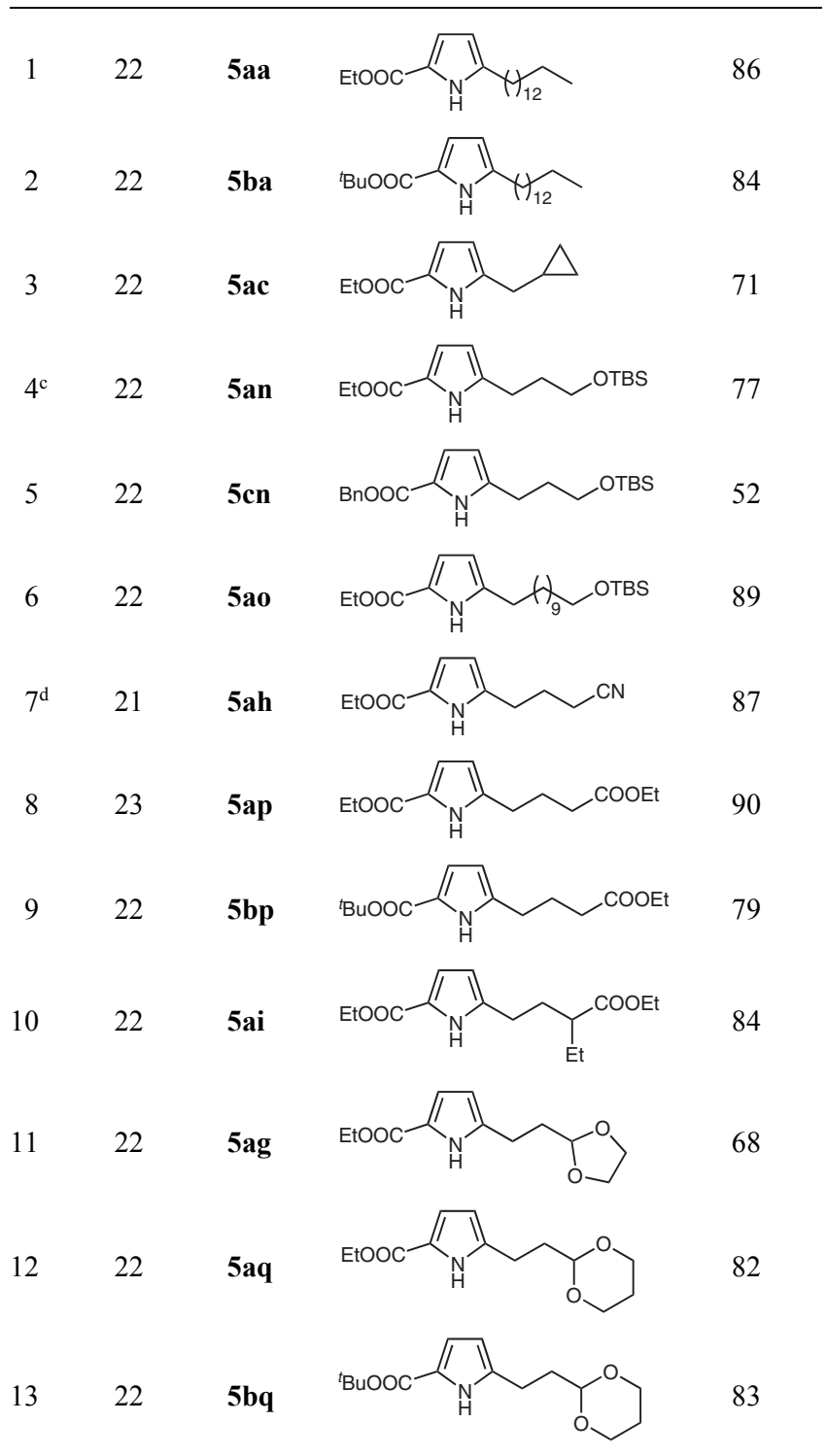

${ }^{\text {a }}$ Reaction conditions: pyrrole 4 ( $\left.1 \mathrm{mmol}\right)$, primary alkyl bromide $\mathbf{2}$ ( 2 $\mathrm{mmol}), \mathrm{PdCl}_{2}(\mathrm{MeCN})_{2}(0.1 \mathrm{mmol})$, norbornene $(2 \mathrm{mmol}), \mathrm{KHCO}_{3}(3$ mmol), DMA $(1 \mathrm{~mL}), 90^{\circ} \mathrm{C}$, under air.

$\mathrm{b}$ Yield of isolated product.

c DMA (3 mL) was used as the solvent.

d The reaction was conducted under 1 atm $\mathrm{O}_{2}$ in a 9:1 v/v mixture of DMA and DMSO.

\section{3}

\section{Summary}

A straightforward and synthetically useful method for the regioselective $\alpha$-alkylation of $\mathrm{NH}$-indoles and pyrroles has been developed that uses a palladium(II)/norbornene cocatalytic system. The method provides a one-step transformation of easily available N-heterocycles and alkyl halides into structurally diverse alkylation products not 
Table 4 Regioselective Direct Alkylation of 2,3-Disubstituted Electron-Deficient $1 H$-Pyrroles $\mathbf{4 d}-\mathbf{i}$ with Primary Alkyl Bromides 2 (Scheme 1, Procedure 2)

Entry ${ }^{\mathrm{a}}$ Time (h) Product

${ }^{\text {a }}$ Reaction conditions: pyrrole 4 ( 1 equiv), primary alkyl bromide 2 ( 2 equiv), $\mathrm{PdCl}_{2}(\mathrm{MeCN})_{2}$ (0.1 equiv), norbornene (2 equiv), $\mathrm{KHCO}_{3}(3$ equiv), DMA ( $1 \mathrm{~mL}$ per mmol of pyrrole substrate $4, c=1 \mathrm{M}), 90^{\circ} \mathrm{C}$, under air.

${ }^{\mathrm{b}}$ Yield based on recovered starting material.

${ }^{c} \mathrm{BuBr}$ (4 equiv) and $\mathrm{KHCO}_{3}$ (5 equiv) were used.

${ }^{\mathrm{d}} c=0.2 \mathrm{M}$.

${ }^{\mathrm{e}} \mathrm{K}_{2} \mathrm{HPO}_{4}$ (3 equiv) as base.

readily available by conventional synthetic methods. The utility of this method was demonstrated by total syntheses of several indole- and pyrrole-based natural products.

Particulars of the reagents, substrates, and other chemicals that were used, together with analytical details, can be found in the appropriate references. ${ }^{10 a, b, 11}$

\section{Procedures}

Typical procedures for the various substrate classes shown in the schemes and in the tables are described below. Procedure 1 is subdivided into two variants ( $1 \mathrm{a}$ and $1 \mathrm{~b}$ ) that require modification of the catalyst and the solvent.

Procedure 1a (Tables 1 and 2)

A 50-mL Schlenk flask equipped with a magnetic stirring bar and a rubber septum was charged with $1 H$-indole substrate $1(1.00 \mathrm{mmol})$, norbornene (188 mg, $2.00 \mathrm{mmol})$, the base $\left[\mathrm{K}_{2} \mathrm{CO}_{3}(276 \mathrm{mg}, 2.00\right.$ $\mathrm{mmol}$ ), $\mathrm{KHCO}_{3}$ (300 mg, $3.00 \mathrm{mmol}$ ), or $\mathrm{K}_{2} \mathrm{HPO}_{4}(522 \mathrm{mg}, 3.00$ $\mathrm{mmol})$ as indicated], and $\mathrm{PdCl}_{2}\left(\mathrm{MeCN}_{2}(25.9 \mathrm{mg}, 0.100 \mathrm{mmol})\right.$. A $0.5 \mathrm{M}$ solution of $\mathrm{H}_{2} \mathrm{O}$ in DMA $(5 \mathrm{~mL})$ was added. The alkyl bromide $2(2.00 \mathrm{mmol})$ was then added from a syringe, and the resulting mixture was degassed by three freeze-pump-thaw cycles with liquid nitrogen under high vacuum. The flask was then placed in an oil bath preheated to $70^{\circ} \mathrm{C}$ or $90^{\circ} \mathrm{C}$, as indicated, and the mixture was stirred vigorously under balloon pressure of argon. Upon completion of the reaction (TLC), the mixture was cooled to r.t., diluted with $\mathrm{Et}_{2} \mathrm{O}(30 \mathrm{~mL})$, and filtered. The filtrate was concentrated in a rotary evaporator $\left(60{ }^{\circ} \mathrm{C}\right.$ water bath, $8-10$ mbar) to remove the $\mathrm{Et}_{2} \mathrm{O}$ and most of the DMA. The residue was purified directly by flash column chromatography [silica gel (dry loading)] to give the alkylation product 3 .

Analytical data for representative 2-alkyl- $1 H$-indole products 3aa, 3bd, 3ee, and 3ij are provided below. Data for other products can be found in the appropriate reference. ${ }^{10 a}$

\section{2-Tetradecyl-1H-indole (3aa)}

White solid; yield: $213 \mathrm{mg}(0.679 \mathrm{mmol}, 67 \%) ; R_{f}=0.64$ (pentane$\left.\mathrm{Et}_{2} \mathrm{O}, 9: 1, \mathrm{UV}\right) ; \mathrm{mp} 58-60^{\circ} \mathrm{C}$.

IR (ATR): 3413, 2916, 2847, 1616, 1584, 1551, 1457, 1408, 1290, $1231 \mathrm{~cm}^{-1}$.

${ }^{1} \mathrm{H}$ NMR $\left(500 \mathrm{MHz}, \mathrm{CDCl}_{3}\right): \delta=0.88(\mathrm{t}, J=7.0 \mathrm{~Hz}, 3 \mathrm{H}), 1.23$ $1.34(\mathrm{~m}, 20 \mathrm{H}), 1.35-1.42(\mathrm{~m}, 2 \mathrm{H}), 1.71$ (app quin, $J \approx 7.5 \mathrm{~Hz}, 2$ H), $2.74(\mathrm{t}, J=7.6 \mathrm{~Hz}, 2 \mathrm{H}), 6.21$ (br s, $1 \mathrm{H}), 7.06$ (app dt, $J=0.9$, $J \approx 7.5 \mathrm{~Hz}, 1 \mathrm{H}), 7.10(\operatorname{app} \mathrm{dt}, J=0.9, J \approx 7.5 \mathrm{~Hz}, 1 \mathrm{H}), 7.29(\mathrm{~d}$, $J=7.9 \mathrm{~Hz}, 1 \mathrm{H}), 7.52$ (d, $J=7.2 \mathrm{~Hz}, 1 \mathrm{H}), 7.83$ (br s, $1 \mathrm{H})$.

${ }^{13} \mathrm{C}$ NMR $\left(90.6 \mathrm{MHz}, \mathrm{CDCl}_{3}\right): \delta=14.3,22.8,28.5,29.3,29.49$, $29.52,29.6,29.7,29.81,29.85,32.1,99.6,110.4,119.7,119.9$, 121.1, 129.0, 136.0, 140.2.

MS (EI, $70 \mathrm{eV}): m / z(\%)=313(45)\left[\mathrm{M}^{+}\right], 144(45)\left[\mathrm{M}-\mathrm{C}_{12} \mathrm{H}_{25}\right]^{+}$, $130(100)\left[\mathrm{M}-\mathrm{C}_{13} \mathrm{H}_{27}\right]^{+}$.

HRMS (EI, $70 \mathrm{eV}$ ): $\mathrm{m} / z\left[\mathrm{M}^{+}\right]$calcd for $\mathrm{C}_{22} \mathrm{H}_{35} \mathrm{~N}: 313.2764$; found: 313.2759 .

\section{7-Methyl-2-\{2-[tert-butyl(dimethyl)siloxy]ethyl\}-1H-indole} (3bd)

Pale-yellow oil; yield: $196 \mathrm{mg}$ (0.677 mmol, 68\%); $R_{f}=0.65$ (pentane- $\mathrm{Et}_{2} \mathrm{O}, 9: 1, \mathrm{UV}$ ).

IR (ATR): 3437, 2954, 2927, 2856, 1614, 1559, 1496, 1461, 1329, $1254 \mathrm{~cm}^{-1}$.

${ }^{1} \mathrm{H}$ NMR $\left(500 \mathrm{MHz}, \mathrm{CDCl}_{3}\right): \delta=0.10(\mathrm{~s}, 6 \mathrm{H}), 0.97(\mathrm{~s}, 9 \mathrm{H}), 2.45$ $(\mathrm{s}, 3 \mathrm{H}), 2.98(\mathrm{t}, J=5.6 \mathrm{~Hz}, 2 \mathrm{H}), 3.94(\mathrm{t}, J=5.6 \mathrm{~Hz}, 2 \mathrm{H}), 6.22(\mathrm{~s}$, $1 \mathrm{H}), 6.91(\mathrm{~d}, J=7.2 \mathrm{~Hz}, 1 \mathrm{H}), 6.98(\operatorname{app} \mathrm{t}, J \approx 7.5 \mathrm{~Hz}, 1 \mathrm{H}), 7.38$ (d, $J=7.8 \mathrm{~Hz}, 1 \mathrm{H}), 8.70$ (br s, $1 \mathrm{H})$.

${ }^{13} \mathrm{C} \mathrm{NMR}\left(90.6 \mathrm{MHz}, \mathrm{CDCl}_{3}\right): \delta=-5.3,16.9,18.3,26.1,31.2,63.3$, $100.3,117.7,119.68,119.70,121.7,127.9,135.7,138.3$.

MS (EI, $70 \mathrm{eV}): m / z(\%)=289(21)\left[\mathrm{M}^{+}\right], 232(100)\left[\mathrm{M}-\mathrm{C}_{4} \mathrm{H}_{9}\right]^{+}$, 158 (26) [M - TBSO $]^{+}, 109$ (36).

HRMS (EI, $70 \mathrm{eV}$ ): $\mathrm{m} / z\left[\mathrm{M}^{+}\right]$calcd for $\mathrm{C}_{17} \mathrm{H}_{27} \mathrm{NOSi}$ : 289.1856; found: 289.1856 . 


\section{6-Chloro-2-[2-(tetrahydro-2 $H$-pyran-2-yloxy)ethyl]-1 $H$-indole}

(3ee)

Pale-yellow oil; yield: $212 \mathrm{mg}(0.758 \mathrm{mmol}, 76 \%) ; R_{f}=0.29$ (pentane- $\left.\mathrm{Et}_{2} \mathrm{O}, 2: 1, \mathrm{UV}\right)$.

IR (ATR): 3256, 2950, 2878, 1616, 1580, 1541, 1457, 1293, 1201 $\mathrm{cm}^{-1}$.

${ }^{1} \mathrm{H}$ NMR $\left(500 \mathrm{MHz}, \mathrm{CDCl}_{3}\right): \delta=1.53-1.68(\mathrm{~m}, 4 \mathrm{H}), 1.75-1.81(\mathrm{~m}$, $1 \mathrm{H}), 1.83-1.89(\mathrm{~m}, 1 \mathrm{H}), 3.02$ (app t, $J \approx 5.9 \mathrm{~Hz}, 2 \mathrm{H}), 3.48-3.53$ $(\mathrm{m}, 1 \mathrm{H}), 3.71$ (app dt, $J=9.6, J \approx 5.9 \mathrm{~Hz}, 1 \mathrm{H}), 3.81-3.85(\mathrm{~m}, 1 \mathrm{H})$, $4.05(\mathrm{dt}, J=9.6, J \approx 5.9 \mathrm{~Hz}, 1 \mathrm{H}), 4.63(\mathrm{dd}, J=4.8,2.8 \mathrm{~Hz}, 1 \mathrm{H})$, $6.21-6.22(\mathrm{~m}, 1 \mathrm{H}), 7.02(\mathrm{dd}, J=8.4,1.9 \mathrm{~Hz}, 1 \mathrm{H}), 7.26-7.29(\mathrm{~m}, 1$ $\mathrm{H}), 7.41(\mathrm{~d}, J=8.4 \mathrm{~Hz}, 1 \mathrm{H}), 8.64($ br s, $1 \mathrm{H})$.

${ }^{13} \mathrm{C} \mathrm{NMR}\left(90.6 \mathrm{MHz}, \mathrm{CDCl}_{3}\right.$ ): $\delta=20.1,25.4,28.7,31.0,63.0,67.3$, 99.7, 100.1, 110.6, 120.2, 120.7, 126.9, 127.1, 136.5, 138.8 .

MS (EI, $70 \mathrm{eV}): m / z(\%)=281(11)\left[\mathrm{M}^{+},{ }^{37} \mathrm{Cl}\right], 279(25)\left[\mathrm{M}^{+},{ }^{35} \mathrm{Cl}\right]$, 232 (6), 195 (73), 177 (31), 164 (100), 85 (61).

HRMS (EI, $70 \mathrm{eV}$ ): $\mathrm{m} / z\left[\mathrm{M}^{+}\right]$calcd for $\mathrm{C}_{15} \mathrm{H}_{18}{ }^{35} \mathrm{ClNO}_{2}: 279.1021$; found: 279.1017 .

Methyl 2-(5-Ethoxy-5-oxopentyl)-1 $H$-indole-5-carboxylate (3ij) White solid; yield: $266 \mathrm{mg}(0.877 \mathrm{mmol}, 87 \%) ; R_{f}=0.30$ (pentane$\left.\mathrm{Et}_{2} \mathrm{O}, 9: 1, \mathrm{UV}\right) ; \mathrm{mp} 91-92^{\circ} \mathrm{C}$.

IR (ATR): 3336, 2932, 2861, 1712, 1695, 1614, 1556, 1439, 1325, $1292,1238 \mathrm{~cm}^{-1}$.

${ }^{1} \mathrm{H}$ NMR $\left(500 \mathrm{MHz}, \mathrm{CDCl}_{3}\right): \delta=1.25(\mathrm{t}, J=7.1 \mathrm{~Hz}, 3 \mathrm{H}), 1.69$ $1.80(\mathrm{~m}, 4 \mathrm{H}), 2.35(\mathrm{t}, J=7.0 \mathrm{~Hz}, 2 \mathrm{H}), 2.77(\mathrm{t}, J=7.0 \mathrm{~Hz}, 2 \mathrm{H})$, $3.92(\mathrm{~s}, 3 \mathrm{H}), 4.13(\mathrm{q}, J=7.1 \mathrm{~Hz}, 2 \mathrm{H}), 6.31(\mathrm{~m}, 1 \mathrm{H}), 7.28(\mathrm{~d}$, $J=8.5 \mathrm{~Hz}, 1 \mathrm{H}), 7.83(\mathrm{dd}, J=8.5,1.7 \mathrm{~Hz}, 1 \mathrm{H}), 8.28(\mathrm{~m}, 1 \mathrm{H}), 8.52$ (br s, $1 \mathrm{H}$ ).

${ }^{13} \mathrm{C} \mathrm{NMR}\left(90.6 \mathrm{MHz}, \mathrm{CDCl}_{3}\right): \delta=14.3,24.5,27.9,28.5,34.0,51.9$, $60.5,100.9,110.2,121.7,122.7,122.8,128.5,138.8,141.0,168.6$, 173.8 .

MS (EI, $70 \mathrm{eV}): m / z(\%)=303(56)\left[\mathrm{M}^{+}\right], 257(34), 201(100), 188$ (68), 170 (26), 129 (21).

HRMS (EI, $70 \mathrm{eV}$ ): $\mathrm{m} / z\left[\mathrm{M}^{+}\right]$calcd for $\mathrm{C}_{17} \mathrm{H}_{21} \mathrm{NO}_{4}$ : 303.1465 ; found: 303.1456 .

Ethyl ( \pm )-4-[3-(2-\{[tert-Butyl(dimethyl)silyl]oxy\}ethyl)-1H-indol-2-yl]-2-ethylbutanoate (3nm); Procedure 1b (Scheme 3) ${ }^{10 b}$ A 250-mL round-bottom flask equipped with a magnetic stirring bar and a rubber septum was charged with indole 1n (1.55 g, 5.63 $\mathrm{mmol}$ ), norbornene (1.06 g, $11.3 \mathrm{mmol}), \mathrm{K}_{2} \mathrm{CO}_{3}$ (3.12 g, 22.6 mmol), alkyl iodide $2 \mathrm{~m}(6.11 \mathrm{~g}, 22.6 \mathrm{mmol})$, and $\mathrm{PdCl}_{2}(100 \mathrm{mg}$, $0.564 \mathrm{mmol})$. Anhydrous DMF $(25.3 \mathrm{~mL})$, anhydrous DMSO (2.8 $\mathrm{mL})$, and $\mathrm{H}_{2} \mathrm{O}$ (269 mg, $\left.14.9 \mathrm{mmol}\right)$ were then added sequentially. The flask was placed in a preheated oil bath at $60^{\circ} \mathrm{C}$ and the mixture was stirred under a balloon pressure of air for $26 \mathrm{~h}$. The mixture was then cooled to r.t. and diluted with $\mathrm{Et}_{2} \mathrm{O}(50 \mathrm{~mL}) . \mathrm{H}_{2} \mathrm{O}$ was added to dissolve inorganic salts, and the resulting mixture was extracted with $\mathrm{Et}_{2} \mathrm{O}(3 \times 50 \mathrm{~mL})$. The extracts were combined, washed with brine, dried $\left(\mathrm{Na}_{2} \mathrm{SO}_{4}\right)$, filtered, and concentrated. The residue was purified by flash column chromatography [silica gel, pentane- $\mathrm{Et}_{2} \mathrm{O}$ $(15: 1$ to $5: 1)$ ] to give a pale-brown oil [yield: $1.71 \mathrm{~g}(73 \%)$ $R_{f}=0.49$ (pentane- $\left.\left.\mathrm{Et}_{2} \mathrm{O}, 2: 1, \mathrm{UV}\right)\right]$, together with recovered starting material $1 \mathrm{n}$ ( $243 \mathrm{mg}, 16 \%$ recovery).

IR (ATR): 3391, 2930, 2856, 1732, 1715, 1462, 1385, 1254, 1192 $\mathrm{cm}^{-1}$.

${ }^{1} \mathrm{H} \mathrm{NMR}\left(500 \mathrm{MHz}, \mathrm{CDCl}_{3}\right): \delta=0.02(\mathrm{~s}, 6 \mathrm{H}), 0.89(\mathrm{t}, J=7.4 \mathrm{~Hz}$, $3 \mathrm{H}), 0.892(\mathrm{~s}, 9 \mathrm{H}), 1.29(\mathrm{t}, J=7.1 \mathrm{~Hz}, 3 \mathrm{H}), 1.46-1.54(\mathrm{~m}, 1 \mathrm{H})$, $1.63-1.70(\mathrm{~m}, 1 \mathrm{H}), 1.75$ (app ddt, $J=12.9,4.6 \mathrm{~Hz}, J \approx 8.2 \mathrm{~Hz}, 1$ H), 1.94-2.01 (m, $1 \mathrm{H}), 2.33-2.38(\mathrm{~m}, 1 \mathrm{H}), 2.66$ (app dt, $J=14.9$ $\mathrm{Hz}, J \approx 8.1 \mathrm{~Hz}, 1 \mathrm{H}), 2.79$ (ddd, $J=14.9,8.6,5.4 \mathrm{~Hz}, 1 \mathrm{H}), 2.88$ 2.97 (m, $2 \mathrm{H}), 3.77$ (t, $J=7.8 \mathrm{~Hz}, 2 \mathrm{H}), 4.19$ (q, $J=7.1 \mathrm{~Hz}, 2 \mathrm{H})$, 7.06 (app dt, $J=1.1 \mathrm{~Hz}, J \approx 7.4 \mathrm{~Hz}, 1 \mathrm{H}), 7.11$ (app dt, $J=1.1 \mathrm{~Hz}$,
$J \approx 7.5 \mathrm{~Hz}, 1 \mathrm{H}), 7.28(\mathrm{~d}, J=7.9 \mathrm{~Hz}, 1 \mathrm{H}), 7.51(\mathrm{~d}, J=7.7 \mathrm{~Hz}, 1 \mathrm{H})$, 8.16 (br s, $1 \mathrm{H})$.

${ }^{13} \mathrm{C}$ NMR (90.6 MHz, $\left.\mathrm{CDCl}_{3}\right): \delta=-5.1,11.9,14.5,18.6,24.1,25.8$, $26.2,28.4,32.8,46.9,60.6,64.0,108.4,110.6,118.3,119.2,121.2$, $128.8,135.4,135.5,176.3$.

MS (EI, $70 \mathrm{eV}): m / z(\%)=417(29)\left[\mathrm{M}^{+}\right], 360(27)\left[\mathrm{M}-\mathrm{C}_{4} \mathrm{H}_{9}\right]^{+}$, 314 (12), 272 (100) [M - $\left.\mathrm{CH}_{2} \mathrm{OTBS}\right]^{+}, 240$ (30), 198 (30).

HRMS (EI, $70 \mathrm{eV}$ ): $m / z\left[\mathrm{M}^{+}\right]$calcd for $\mathrm{C}_{24} \mathrm{H}_{39} \mathrm{NO}_{3} \mathrm{Si}: 417.2694$; found: 417.2691 .

\section{Procedure 2 (Tables 3 and 4$)^{11}$}

A reaction tube $(30 \times 190 \mathrm{~mm})$ equipped with a magnetic stirring bar and a rubber septum was charged with $1 H$-pyrrole substrate $\mathbf{4}$ $(1.00 \mathrm{mmol})$, norbornene $(188 \mathrm{mg}, 2.00 \mathrm{mmol}), \mathrm{KHCO}_{3}(300 \mathrm{mg}$, $3.00 \mathrm{mmol}), \mathrm{PdCl}_{2}\left(\mathrm{MeCN}_{2}(25.9 \mathrm{mg}, 0.100 \mathrm{mmol})\right.$, and alkyl bromide $2(2.00 \mathrm{mmol})$. Anhydrous DMA $(1 \mathrm{~mL})$ was added, and the tube was heated in an aluminum block at $90{ }^{\circ} \mathrm{C}$ under a balloon pressure of air. When the reaction was complete (TLC), the mixture was cooled to r.t., diluted with $\mathrm{Et}_{2} \mathrm{O}(30 \mathrm{~mL})$, and filtered. The filtrate was washed with $\mathrm{H}_{2} \mathrm{O}(20 \mathrm{~mL})$, and the organic phase was separated. The aqueous layer was extracted with $\mathrm{Et}_{2} \mathrm{O}(2 \times 20 \mathrm{~mL})$. The organic layers were combined, washed with brine $(40 \mathrm{~mL})$, dried $\left(\mathrm{Na}_{2} \mathrm{SO}_{4}\right)$, filtered, and concentrated. The crude product was purified by flash column chromatography (silica gel) to afford the alkylation product 5 .

Analytical data for representative pyrrole alkylation products $\mathbf{5 a p}$, $\mathbf{5 f q}$, and 5iq are provided below. Data for other products can be found in the corresponding reference. ${ }^{11}$

Ethyl 5-(4-Ethoxy-4-oxobutyl)-1H-pyrrole-2-carboxylate (5ap) Pale-yellow solid; yield: $228 \mathrm{mg}(0.900 \mathrm{mmol}, 90 \%) ; R_{f}=0.15$ (pentane- $\mathrm{Et}_{2} \mathrm{O}, 3: 1, \mathrm{UV}$ ); $\mathrm{mp} 54-56^{\circ} \mathrm{C}$.

IR (ATR): 3224, 2978, 1719, 1683, $1201 \mathrm{~cm}^{-1}$.

${ }^{1} \mathrm{H}$ NMR $\left(500 \mathrm{MHz}, \mathrm{CDCl}_{3}\right): \delta=1.25(\mathrm{t}, J=7.1 \mathrm{~Hz}, 3 \mathrm{H}), 1.35(\mathrm{t}$, $J=7.1 \mathrm{~Hz}, 3 \mathrm{H}), 1.97$ (app quin, $J \approx 7.4 \mathrm{~Hz}, 2 \mathrm{H}), 2.33(\mathrm{t}, J=7.3$ $\mathrm{Hz}, 2 \mathrm{H}), 2.69(\mathrm{t}, J=7.5 \mathrm{~Hz}, 2 \mathrm{H}), 4.13(\mathrm{q}, J=7.1 \mathrm{~Hz}, 2 \mathrm{H}), 4.30$ (q, $J=7.1 \mathrm{~Hz}, 2 \mathrm{H}), 5.98($ app t, $J \approx 3.2 \mathrm{~Hz}, 1 \mathrm{H}), 6.83(\mathrm{dd}, J=3.7,2.5$ $\mathrm{Hz}, 1 \mathrm{H}), 9.44$ (br s, $1 \mathrm{H})$.

${ }^{13} \mathrm{C} \mathrm{NMR}\left(90.6 \mathrm{MHz}, \mathrm{CDCl}_{3}\right): \delta=14.3,14.6,24.8,27.1,33.5,60.2$, $60.5,108.5,116.0,121.7,137.5,161.5,173.3$.

MS (EI, $70 \mathrm{eV}): m / z(\%)=253(60)\left[\mathrm{M}^{+}\right], 207$ (35), $165(70), 152$ (100), $106(75)$.

HRMS (EI, $70 \mathrm{eV}$ ): $\mathrm{m} / z\left[\mathrm{M}^{+}\right]$calcd for $\mathrm{C}_{13} \mathrm{H}_{19} \mathrm{NO}_{4}$ : 253.1309; found: 253.1305 .

\section{Ethyl 5-[2-(1,3-Dioxan-2-yl)ethyl]-2-methyl-1H-pyrrole-3-car-} boxylate (5fq)

Pale-purple oil; yield: $165 \mathrm{mg}$ ( $0.617 \mathrm{mmol}, 61 \%$; $71 \%$ based on recovered pyrrole substrate $\mathbf{4 f}$ ); $R_{f}=0.20$ (pentane- $\mathrm{Et}_{2} \mathrm{O}, 1: 2, \mathrm{UV}$ ).

IR (ATR): 3278, 2926, 1655, 1458, $1232 \mathrm{~cm}^{-1}$.

${ }^{1} \mathrm{H}$ NMR $\left(500 \mathrm{MHz}, \mathrm{CDCl}_{3}\right): \delta=1.32(\mathrm{t}, J=7.1 \mathrm{~Hz}, 3 \mathrm{H}), 1.34$ $1.38(\mathrm{~m}, 1 \mathrm{H}), 1.88(\mathrm{dt}, J=5.0,7.4 \mathrm{~Hz}, 2 \mathrm{H}), 2.09$ (app tq, $J=5.0$ $\mathrm{Hz}, J \approx 12.8 \mathrm{~Hz}, 1 \mathrm{H}), 2.47$ (s, $3 \mathrm{H}), 2.64(J=7.4 \mathrm{~Hz}, 2 \mathrm{H}), 3.74$ $3.80(\mathrm{~m}, 2 \mathrm{H}), 4.12(\mathrm{dd}, J=11.7,5.0 \mathrm{~Hz}, 2 \mathrm{H}), 4.24(\mathrm{q}, J=7.1 \mathrm{~Hz}$, $2 \mathrm{H}), 4.57(\mathrm{t}, J=5.0 \mathrm{~Hz}, 1 \mathrm{H}), 6.21(\mathrm{~d}, J=2.9 \mathrm{~Hz}, 1 \mathrm{H}), 8.69$ (br s, $1 \mathrm{H})$.

${ }^{13} \mathrm{C} \mathrm{NMR}\left(90.6 \mathrm{MHz}, \mathrm{CDCl}_{3}\right): \delta=13.3,14.6,21.5,25.8,34.5,59.3$, 66.9, 101.5, 106.8, 111.4, 130.0, 134.4, 166.0.

MS (EI, $70 \mathrm{eV}): m / z(\%)=267(60)\left[\mathrm{M}^{+}\right], 222(33), 205(100), 166$ (49), 131 (76).

HRMS (EI, $70 \mathrm{eV}$ ): $\mathrm{m} / z\left[\mathrm{M}^{+}\right]$calcd for $\mathrm{C}_{14} \mathrm{H}_{21} \mathrm{NO}_{4}$ : 267.1465; found: 267.1463 . 
Ethyl 3-Chloro-5-[2-(1,3-dioxan-2-yl)ethyl]-1H-pyrrole-2-carboxylate (5iq)

White solid; yield: $257 \mathrm{mg}(0.893 \mathrm{mmol}, 91 \%) ; R_{f}=0.13$ (pentaneEtOAc 4:1, UV); mp 93-94 ${ }^{\circ} \mathrm{C}$.

IR (ATR): 3276, 2969, 1673, $1491 \mathrm{~cm}^{-1}$.

${ }^{1} \mathrm{H}$ NMR $\left(500 \mathrm{MHz}, \mathrm{CDCl}_{3}\right): \delta=1.37(\mathrm{t}, J=7.2 \mathrm{~Hz}, 3 \mathrm{H}), 1.37$ $1.40(\mathrm{~m}, 1 \mathrm{H}), 1.92(\operatorname{app~q}, J \approx 6.3 \mathrm{~Hz}, 2 \mathrm{H}), 2.06-2.16(\mathrm{~m}, 1 \mathrm{H})$, $2.72(\mathrm{t}, J=7.0 \mathrm{~Hz}, 2 \mathrm{H}), 3.79($ app t $, J \approx 11.8 \mathrm{~Hz}, 2 \mathrm{H}), 4.16(\mathrm{dd}$, $J=11.6,4.9 \mathrm{~Hz}, 2 \mathrm{H}), 4.34(\mathrm{q}, J=7.2 \mathrm{~Hz}, 2 \mathrm{H}), 4.59(\mathrm{t}, J=4.7 \mathrm{~Hz}$, $1 \mathrm{H}), 5.96(\mathrm{~d}, J=2.9 \mathrm{~Hz}, 1 \mathrm{H}), 9.62(\mathrm{br} \mathrm{s}, 1 \mathrm{H})$.

${ }^{13} \mathrm{C}$ NMR $\left(126 \mathrm{MHz}, \mathrm{CDCl}_{3}\right): \delta=14.6,21.9,25.8,33.8,60.5,67.1$, 101.0, 109.8, 117.0, 119.2, 136.6, 160.4.

MS (EI, $70 \mathrm{eV}): m / z(\%)=289(30)\left[\mathrm{M}^{+},{ }^{37} \mathrm{Cl}\right], 287(90)\left[\mathrm{M}^{+},{ }^{35} \mathrm{Cl}\right]$, 212 (85), 140 (100), 114 (70), 101 (89).

HRMS (EI, $70 \mathrm{eV}$ ): $\mathrm{m} / z\left[\mathrm{M}^{+}\right]$calcd for $\mathrm{C}_{13} \mathrm{H}_{18}{ }^{35} \mathrm{ClNO}_{4}$ : 287.0919; found: 287.0918 .

\section{Acknowledgement}

This project was supported by the Deutsche Forschungsgemeinschaft (Ba 1372/19-1). L.J. acknowledges the Alexander von Humboldt Foundation for a postdoctoral fellowship.

\section{References}

(1) (a) Sundberg, R. J. Indoles; Academic Press: San Diego, 1996. (b) Sundberg, R. J. In Comprehensive Heterocyclic Chemistry II; Vol. 2; Katritzky, A. R.; Rees, C. W.; Scriven, E. F. V., Eds.; Pergamon: Oxford, 1996, 119. (c) Joule, J. A. In Science of Synthesis, Thomas E. J; Vol. 10; Thieme: Stuttgart, 2000, 361. (d) Gribble, G. W. J. Chem. Soc., Perkin Trans. 1 2000, 1045. (e) Tois, J.; Franzén, R.; Koskinen, A. Tetrahedron 2003, 59, 5395. (f) d'Ischia, M.; Napolitano, A.; Pezzella, A. In Comprehensive Heterocyclic Chemistry III; Vol. 3; Katritzky, A. R.; Ramsden, C. A.; Scriven, E. F. V.; Taylor, R. J. K., Eds.; Elsevier: Amsterdam, 2008, Chap. 1-4.

(2) (a) Atta-ur-Rahman; Basha, A. Indole Alkaloids; Harwood Academic: Amsterdam, 1997. (b) Gribble, G. W. In Rodd's Chemistry of Carbon Compounds, 2nd ed., Suppl. 2, Vol. IV; Sainsbury, M., Ed.; Elsevier: Amsterdam, 1997, Chap. 9, 69. (c) Mal, D.; Shome, B.; Dinda, B. K. In Heterocycles in Natural Product Synthesis; Majumdar, K. C.; Chattopadhyay, S. K., Eds.; Wiley-VCH: Weinheim, 2011, 187.

(3) For reviews, see: (a) Cacchi, S.; Fabrizi, G. Chem. Rev. 2005, 105, 2873. (b) Seregin, I. V.; Gevorgyan, V. Chem. Soc. Rev. 2007, 36, 1173. (c) Joucla, L.; Djakovitch, L. $A d v$. Synth. Catal. 2009, 351, 673. (d) Bandini, M.; Eichholzer, A. Angew. Chem. Int. Ed. 2009, 48, 9608. (e) Beck, E. M.; Gaunt, M. J. Top. Curr. Chem. 2010, 292, 85. (f) Broggini, G.; Beccalli, E. M.; Fasana, A.; Gazzola, S. Beilstein J. Org. Chem. 2012, 8, 1730.

(4) Joule, J. A.; Mills, K. Heterocyclic Chemistry, 5th ed.; Wiley: Chichester, 2010, 373.

(5) The direct C2 functionalization of indole can be achieved through $\mathrm{C} 2$-lithiation of $\mathrm{N}$-protected indoles. For examples, see: (a) Shirley, D. A.; Roussel, P. A. J. Am. Chem. Soc. 1953, 75, 375. (b) Sundberg, R. J.; Russell, H. F. J. Org. Chem. 1973, 38, 3324. (c) Hasan, I.; Marinelli, E. R.; Lin, L. C.; Fowler, F. W.; Levy, A. B. J. Org. Chem. 1981, 46, 157. (d) Katritzky, A. R.; Akutagawa, K. Tetrahedron Lett. 1985, 26, 5935. (e) Gharpure, M.; Stoller, A.; Bellamy, F.; Firnau, G.; Snieckus, V. Synthesis 1991, 1079. (f) Fukuda, T.; Mine, Y.; Iwao, M. Tetrahedron 2001, 57, 975. (g) De Simone, F.; Gertsch, J.; Waser, J. Angew. Chem. Int. Ed. 2010, 49, 5767.

(6) (a) Nakao, Y.; Kashihara, N.; Kanyiva, K. S.; Hiyama, T. Angew. Chem. Int. Ed. 2010, 49, 4451. (b) Nagib, D. A.; MacMillan, D. W. C. Nature (London) 2011, 480, 224.

(c) Lee, D.-H.; Kwon, K.-H.; Yi, C. S. Science (Washington D. C.) 2011, 333, 1613. (d) Ding, Z.; Yoshikai, N. Beilstein J. Org. Chem. 2012, 8, 1536. (e) Pan, S.; Ryu, N.; Shibata, T. J. Am. Chem. Soc. 2012, 134, 17474.

(7) (a) Skell, P. S.; Bean, G. P. J. Am. Chem. Soc. 1962, 84, 4655. (b) Griffin, C. E.; Obrycki, R. J. Org. Chem. 1964, 29 , 3090. (c) Castro, A. J.; Deck, J. F.; Ling, N. C.; Marsh, J. P. Jr.; Means, G. E. J. Org. Chem. 1965, 30, 344. (d) Bean, G. P. J. Org. Chem. 1967, 32, 228. (e) Papadopoulos, E. P.; Tabello, K. I. Y. J. Org. Chem. 1968, 33, 1299. (f) Reinecke, M. G.; Sebastian, J. F.; Johnson, H. W. Jr.; Pyun, C. J. Org. Chem. 1972, 37, 3066. (g) Wang, N.-C.; Teo, K.-E.; Anderson, H. J. Can. J. Chem. 1977, 55, 4112.

(8) For selected recent examples of direct alkylation of pyrroles, see: (a) Guerrero, M. A.; Miranda, L. D. Tetrahedron Lett. 2006, 47, 2517. (b) Guadarrama-Morales, O.; Méndez, F.; Miranda, L. D. Tetrahedron Lett. 2007, 48, 4515. (c) Trost, B. M.; Müller, C. J. Am. Chem. Soc. 2008, 130, 2438. (d) Sheng, Y.-F.; Gu, Q.; Zhang, A.-J.; You, S.-L. J. Org. Chem. 2009, 74, 6899. (e) Zaitsev, A. B.; Gruber, S.; Plüss, P. A.; Pregosin, P. S.; Veiros, L. F.; Wörle, M. J. Am. Chem. Soc. 2008, 130, 11604. (f) Liu, Y.; Cao, Z.; Du, H. J. Org. Chem. 2012, 77, 4479. (g) Jorapur, Y. R.; Lee, C.-H.; Chi, D. Y. Org. Lett. 2005, 7, 1231. (h) Jorapur, Y. R.; Chi, D. Y. Bull. Korean Chem. Soc. 2011, 32, 3130.

(9) For reviews, see: (a) Catellani, M. Synlett 2003, 298. (b) Catellani, M. Top. Organomet. Chem. 2005, 14, 21. (c) Catellani, M.; Motti, E.; Della Ca', N. Acc. Chem. Res. 2008, 41, 1512. (d) Martins, A.; Mariampillai, B.; Lautens, M. Top. Curr. Chem. 2010, 292, 1.

(10) (a) Jiao, L.; Bach, T. J. Am. Chem. Soc. 2011, 133, 12990. (b) Jiao, L.; Herdtweck, E.; Bach, T. J. Am. Chem. Soc. 2012, 134, 14563.

(11) Jiao, L.; Bach, T. Angew. Chem. Int. Ed. 2013, 52, 6080.

(12) Bordwell, F. G. Acc. Chem. Res. 1988, 21, 456.

(13) For selected examples, see: (a) Cambie, R. C.; Moratti, S. C.; Rutledge, P. S.; Woodgate, P. D. Synth. Commun. 1990, 20 , 1923. (b) Rolfs, A.; Liebscher, J. Angew. Chem. Int. Ed. Engl. 1993, 32, 712. (c) Hwang, S. H.; Kurth, M. J. Tetrahedron Lett. 2002, 43, 53. (d) Bellur, E.; Langer, P. Tetrahedron Lett. 2006, 47, 2151. (e) Lygin, A. V.; Larionov, O. V.; Korotkov, V. S.; de Meijere, A. Chem. Eur. J. 2009, 15, 227. (f) Bellur, E.; Yawer, M. A.; Hussain, I.; Riahi, A.; Fatunsin, O.; Fischer, C.; Langer, P. Synthesis 2009, 227. (g) Hekmatshoar, R.; Sadjadi, S.; Sadjadi, S.; Heravi, M. M.; Beheshtiha, Y. S.; Bamoharram, F. F. Synth. Commun. 2010, 40, 1708. 